\title{
Various polymerization temperature on dimensional accuracy of orthodontic acrylic base plate
}

Elly Rusdiana

Department of Orthodontic

Faculty of Dentistry Airlangga University

Surabaya - Indonesia

\begin{abstract}
Cold curing acrylic is more porous, having more residual monomer and dimensional change. Physical property of cold curing acrylic shows to have very small dimensional change resulted from imperfect polymerization process and if dimensional change occurs, it would cause improper use of orthodontic appliance. Orthodontic acrylic base plate which is made of cold curing acrylic, in order to achieve good result, it is suggested to use hydro flask or polyclav with water temperature $45^{\circ}-50^{\circ} \mathrm{C}$ and polyclav and pressure in $2-3$ atm during polymerization process. Even though cold curing acrylic could polymerization at room temperature, the purpose to use hydro flask or polyclav is to reduce residual monomer and porosity. The purpose of the present study is to know the difference in dimensional accuracy of orthodontic acrylic at various polymerization temperature. The samples of the study were 18 acrylic base plate sized $65 \times$ $10 \times 25 \mathrm{~mm}$ classified into 3 control groups with polymerization temperature at $30^{\circ} \mathrm{C}, 40^{\circ} \mathrm{C}$ and $50^{\circ} \mathrm{C}$. Measurement was done using caliper in order to know dimensional accuracy of orthodontic acrylic. The measurement result was tabulated and One-Way ANOVA test one was done with significant level 95\%, the probability result 0,0055 was found which means there was significant difference among each control group. LSD test showed that group I polymerization at $30^{\circ} \mathrm{C}$, group II polymerization at $40^{\circ} \mathrm{C}$, and group III polymerization at $50^{\circ} \mathrm{C}$ there was significant difference. The conclusion of this study is : dimensional difference of orthodontic acrylic base plate on polymerization at group I at $30^{\circ} \mathrm{C}$, group II at $40^{\circ} \mathrm{C}$, and group III at $50^{\circ} \mathrm{C}$ water temperature and could achieve better dimensional accuracy comparing with polymerization at $50^{\circ} \mathrm{C}$.
\end{abstract}

Key words: cold curing acrylic, dimension, polymerization

Correspondence: Elly Rusdiana, c/o: Bagian Ortodonsia, Fakultas Kedokteran Gigi Universitas Airlangga. Jln. Mayjend. Prof. Dr. Moestopo no. 47 Surabaya 60132, Indonesia.

\section{INTRODUCTION}

Removable orthodontic appliance consists of several components i.e. active, retention, anchoring and plate acrylic. In line with the advancement and development of dentistry technology, at first heat curing acrylic was applied in the making of removable orthodontic appliance, but at present cold curing acrylic is applied. If heat curing acrylic is used, it is true that it would produce solid plate acrylic, harder, nonporous, more stable color, but, the process is more complicated because wax model should be firstly made and the process of acrylic filling would take time. ${ }^{1}$ The use of cold curing acrylic is more advantageous because this material is more time saving, cheaper, easier working method, the possibility of distortion due to retention or springs could be eliminated as minimally as possible or it could be prevented. This material would also make the process easier if reparation or change should be done in removable orthodontic appliance ${ }^{1}$. The main disadvantage of cold curing acrylic is that: unstable color, and more porousity. $^{2}$ Acrylic base plate of removable orthodontic appliance is an attachment place of active and passive components. The functions of acrylic base plate are to sustain other components, to continue the strength of active component anchoring denture movement, to prevent undesired denture shift, to protect springs on the palate and also to be widened to make bite plane either anteriorly or posteriorly. Acrylic base plate is made too thick, but strong enough so it will not disturb lingual, swallowing function and also well attached on the palate or lingual teeth. ${ }^{3}$

Polymerization is repeated intermolecular reaction between polymer and monomer functionally unlimitedly. ${ }^{2,4}$ For dentistry material polymerization is usually through chemical addition reaction. Polymerization process of cold curing acrylic would run in three stages i.e. initiation, propagation (change spreader) and termination. The free radical contains very reactive free electron and capable to break monomer multiple binding, so, the monomer would become free radical by itself. Propagation (change spreader) would occur because the monomer which is activated has reaction with other monomers, the process would continue until it would reach termination stage. So, in this stage, lengthening change has occurred because the monomer which has been activated is interrelated.

Change of termination (stage of ended change ) appears because of reaction between two change of free radical which is in growing process, therefore, stable molecule is formed. ${ }^{2}$ Imperfect polymerization of cold curing acrylic 
Table 1. The mean difference of orthodontic acrylic base plate dimension with the working model of every group $(\mathrm{mm})$

\begin{tabular}{ccccc}
\hline & Group & Number of sample & Mean & Deviation standard \\
\hline I. & $30^{\circ} \mathrm{C}$ water temperature & 6 & 0.0333 & 0.0258 \\
II. $\quad 40^{\circ} \mathrm{C}$ water temperature & 6 & 0.0200 & 0.0237 \\
III. $\quad 50^{\circ} \mathrm{C}$ water temperature & 6 & 0.0750 & 0.0274 \\
\hline
\end{tabular}

shows the presence of higher residual monomer which resulting irritation in oral tissue and more porosity which could decrease transversal strength. ${ }^{4}$ Physical property of cold curing acrylic shows very small dimensional change resulting from imperfect polymerization process. To obtain nonporous acrylic base plate, in order to achieve tooth strength, good aesthetic, hygienic, low residual monomer so it would not irritate oral tissue. ${ }^{5}$ Houston and Isaacson ${ }^{3}$ suggested that polymerization of acrylic base plate done in hydro flask or polyclav containing warm water $45-50^{\circ} \mathrm{C}$ with the pressure $2-3 \mathrm{~atm}$ and the purpose is to reduce residual monomer and porosity.

American Dental Association ${ }^{6}$ also suggested that to achieve good result by increasing the temperature and giving pressure during polymerization process. Because polymerization of cold curing acrylic was quick process, as a result dimensional change would happen. ${ }^{7,8}$ Cold curing acrylic dimensional change would cause removable orthodontic appliance is not properly used.

The purpose of this study is to know the difference in dimensional accuracy of orthodontic acrylic plate at various polymerization temperature.

\section{MATERIAL AND METHOD}

The present study was done in experimental laboratory study and the materials were: cold curing acrylic resin, hard gypsum and devices were: model master die with diameter $65 \times 10 \times 2,5 \mathrm{~mm}$ metal cuvet, digital balance, polyclav, water thermometer, caliper, bowl, spatula, vibrator, glass plate.

The process of sample making: firstly mould was made using 100 gram hard gypsum mixed $35 \mathrm{ml}$ water (according to factory procedure) was stirred in bowl using spatula, then put in the cuvet and place on the vibrator. Model master die, was put in the middle of the cuvet, the gypsum was flatten using glass plate, finally the gypsum was left hardening. After hardening the model was taken, the mould was soaked in the water for ten minutes, when it was almost dry it was polished by separator material, until it was dry. Filling of acrylic resin into the mould with comparison polymer $3.5 \mathrm{gr}$ and monomer $1.5 \mathrm{ml}$ (according factory procedure) using layering i.e. monomer which was dropped on the mould, then, polymer was spread and monomer dropped again until polymer was absorb and the desired thickness was achieved. Cuvet with acrylic resin was put into polyclav at $30^{\circ} \mathrm{C}, 40^{\circ} \mathrm{C}, 50^{\circ} \mathrm{C}$, water temperature in 2 atmosphere
Table 2. LSD test among every group

\begin{tabular}{llll}
\hline Group & I & II & III \\
\hline I & - & - & + \\
II & - & - & + \\
III & - & - & - \\
\hline
\end{tabular}

Note: - : No significant difference; + : Significant difference

for 10 minutes and next, sample was removed from the cuvet.

The test of dimensional accuracy of acrylic base plate was done by measuring and using caliper on mould before acrylic filling, the different measurement was done on acrylic base plate which was already formed, data analysis using One-Way ANOVA test in order to know the significant difference among every group, LSD test was done.

\section{RESULT}

The result of the study on accurate dimension of acrylic base plate at various polymerization temperature as shown on table 1 . Table 1 show that highest dimensional change occurred in group III $\left(50^{\circ} \mathrm{C}\right.$ water temperature $)$, while the lowest dimensional change in group II $\left(40^{\circ} \mathrm{C}\right.$ water temperature).

To know the presence of difference in variant polymerization temperature on the accuracy of orthodontic acrylic base plate dimension, the above data analyzed using One-Way ANOVA test variant analysis with significance level $95 \%$ was found probability $<0.05$. It could be concluded that there is significant difference in accuracy of orthodontic acrylic base plate in every group. To be able to know significant difference among controlled groups, LSD test was done and it is shown on table 2.

On the above table we could see the dimensional accuracy of orthodontic acrylic base plate in group I and group II no significant difference was found, between group I and III significant difference was found and between group II and III significant difference was also found.

\section{DISCUSSION}

To achieve the success of orthodontic removable appliance, some requirements which are needed are 
appropriate acrylic base plate, nonporous, good aesthetic, hygienic, low residual content, preventing unmovable dental. The making of acrylic resin of removable appliance using cold curing acrylic with finer particles comparing with cold acrylic in Orthodontia. Various cold curing acrylics have the same size of particles. While particle of polymer used in removable orthodontic appliance is $75 \mu \mathrm{m}$. The smaller the size of a particle the quicker the monomer infiltrates. The properties of cold curing acrylic are in higher porosity. Even though it is not easily seen in pigmented resin, it is because the air is dissolved monomer fluid which is not absorbed in polymer powder at room temperature, having satisfying color which is matched with the color of oral Mucosa (pink in color), determined by transitional glass (Tg). Temperature glass transitional of cold curing is $90^{\circ} \mathrm{C}$, so the possibility of distortion of hot water would occur, the glass temperature affects the average of molecular weight of a polymer. In general the average of molecular weight is lower and contains more than $80 \%$ of heat curing material, it is probably correlated with lower molecular weight. The rheology property of heat curing acrylic is better comparing with cold curing, because cold curing material shows higher distortion in implementation. ${ }^{2}$ The result of this study shows that acrylic resin in which the polymerization at $30^{\circ} \mathrm{C}$ water temperature and $40^{\circ} \mathrm{C}$ producing better accurate dimension comparing with polymerization at $50^{\circ} \mathrm{C}$ water temperature. It is possibly because physical property of cold curing acrylic shows every little dimensional change caused by less perfect polymerization process. ${ }^{4}$

On this study $30^{\circ} \mathrm{C}$ was used with consideration that room temperature was about $30^{\circ} \mathrm{C}$, while $40^{\circ} \mathrm{C}$ was matched with polyclav which was used on this study. $50^{\circ}$ $\mathrm{C}$ was according to statement given by $\mathrm{ADA}^{6}$ suggested to increase temperature during polymerization process.

In group I: polymerization at $30^{\circ} \mathrm{C}$, there is not significant difference with polymerization at $40^{\circ} \mathrm{C}$ in groups II. It is possible that cold curing acrylic could polymerize at room temperature due to the presence of chemical activator, ${ }^{7}$ i.e. amino group which is added in monomer fluid to activate benzoil peroxide to form free radical, so polymerization could run at room temperature in which amino tertier: dimetil-p-toludin (DMPT) ${ }^{7}$ is usually used, therefore, $30^{\circ} \mathrm{C}$ water temperature and $40^{\circ} \mathrm{C}$ is not too different with room temperature so there is no significant change found in dimensional acrylic change.

In group II polymerization at $40^{\circ} \mathrm{C}$ water temperature comparing with III polymerization at $50^{\circ} \mathrm{C}$ water temperature, there is significant difference. It is possibly because the temperature is too high comparing to room temperature, so polymerization process would quickly occur. The result of quick polymerization process, dimensional change would occur. ${ }^{7,8}$ The conclusion is the accuracy of orthodontic acrylic base plate dimension in polymerization at $30^{\circ} \mathrm{C}$ and $40^{\circ} \mathrm{C}$ air temperature could produce better dimensional accuracy comparing with polymerization at $50^{\circ} \mathrm{C}$ room temperature.

\section{REFERENCES}

1. Adams CP. The design and construction and use removable orthodontic appliance. $6^{\text {th }}$ ed. London: Butter Worth Haineman Ltd; 1990. p. 209-11.

2. Combe EC. Notes on dental materials. $6^{\text {th }}$ ed. New York: Churchill Livingstone; 1992. p. 79-120.

3. Houston WJB, Isaacson KG. Orthodontic treatment with removable appliances. $2^{\text {nd }}$ ed. Bristol: John Wright \& Sons Ltd; 1992 p. $132-8$.

4. Anusavice KJ. Phillip's science of dental materials. $11^{\text {th }}$ ed. Saint Louis: WB Saunders Company; 2003. p. 207-10.

5. Nuraini I. Sitotoksisitas resin akrilik rapid heat polymerized terhadap kultur sel BHK. Majalah Kedokteran Gigi (Dental Journal) 2004; 37(1):15-18.

6. American Dental Association. Guide to dental material devices. $7^{\text {th }}$ ed. Chicago: American Dental Association 1974; p. 97-102.

7. Anderson JN. Applied dental materials. $5^{\text {th }}$ ed. Oxford: Blackwell Scientific Publications; 1976. 284-95.

8. Craig RG, Obrien WJ, Powers JM. Dental material properties and manipulation. $7^{\text {th }}$ ed. St Louis, Missouri: Mosby Inc; 2000. p. 79-120. 